\title{
Managing some uncertainties of communication as academic discipline in the Spanish and Italian virtual environment
}

\author{
Alina Ţenescu ${ }^{1 *}$, Nicuşor Minculete $^{2}$ \\ ${ }^{1}$ University of Craiova, 13 A. I. Cuza Street, 200585, Craiova, Romania \\ ${ }^{2}$ Transilvania University of Braşov, Department of Mathematics and Computer Science, Romania \\ *E-mail address: stvlad@yahoo.com
}

\begin{abstract}
The premise from which we begin our study is that nowadays we are faced with several uncertainties of communication as academic discipline, amongst which the most evident are: the uncertainty related to the denomination or title of the discipline, the uncertainty concerning its status as theory of communication or as science of communication and the uncertainty regarding the inclusion of communication within one or other of the following domains: social sciences, natural sciences or humanities. Applying the comparative citation analysis on a corpus of study constituted by thirty-two titles of publications representative for the domain of science of information and communication (published in the last twenty years) in two different cultural and scientific areas (Italian and Spanish), we will examine the frequency, patterns, and graphs of citation of these publications in six electronic bookshops. We will also carry out a comparative statistical analysis of the categories and scientific domains these publications are included and comprised in on the virtual platforms so as to reveal the above mentioned uncertainties and to find a solution by proposing a model for the standardization of domain categories and tags of the same title on several bookshop sites.
\end{abstract}

Keywords: academic discipline; communication; uncertainties; comparative citation analysis; Italian and Spanish virtual environment

\section{INTRODUCTION}

In the last fifty years, the communication field has been subject to a spectacular extension. Communication as a field has broadened so that nowadays it includes several other fields and sub-fields: "the study of communication expanded to include many areas and topics that were unknown to the founders of the field - that is interpersonal and family communication, group and organizational communication, health and aging communication, communication media and technology, to name only a few" (Cissna \& Frey, 2009: XXIX). In spite of the fast expansion of the communication field, and of the development of study and research in communication subfields, we are still confronted with a series of uncertainties regarding communication as an academic discipline. A first uncertainty is concerned with the denomination of the discipline, while a second might be directly connected to the status of the discipline communication. A third uncertainty deals with the place that this discipline 
occupies within the framework of sciences/social sciences/social-human sciences/human sciences, whilst a fourth (We have identified a fifth component to the four-variant typology of uncertainties regarding communication as an academic discipline that was first proposed by Ştefan Vlăduţescu in "The Communication Membranes", European Scientific Journal, November 2013, edition vol.9, No.32, ISSN: 1857 - 7881 (Print) e - ISSN 1857- 7431, pp. 84-92. He suggests that a meta-analytical approach that would identify and isolate nuclei of certainty out of the mass of uncertainties might represent the best solution for this issue.) uncertainty might be concerned with the debate on the unification or fragmentation into several specialties of the discipline communication. A fifth uncertainty might be connected to uncertainty avoidance index. The uncertainty avoidance index may deal with the scientists' and researchers' tolerance for uncertainty and ambiguity in the communication field and insofar as communication as an academic discipline and its contents are concerned. It would show to what extent the members of the scientific community and also the students in communication or the readers feel either uncomfortable or comfortable when confronted with the unstructured and undisciplined fields of study of communication.

The greater and the more obvious these uncertainties become, two different behaviours arise: an uncertainty avoiding scientific community tries to minimize the uncertainties that appear by imposing strict or too rigorous models, patterns of communication and try to find safety measures, but do not really solve the uncertainties, attempting to plan everything carefully when conducting research or teaching and proceed to changes step by step, whilst a low avoidance scientific community will have no trouble in acknowledging the indiscipline in the fields of study of communication and deal with the uncertain and unknown, trying to understand the meaning of these uncertainties and not conceal them under safe models or theories.

The uncertainty concerning the title of the discipline brings about the fact that there is not still any convergence regarding the way the discipline is denominated. The uncertainty is revealed by the existence of a wide range of denominations under which communication is studied: "communication", "communication studies", "communication science", "sciences de l'information et de la communication".

The uncertainty referring to the status of the discipline points out the constant alternation between science and theory of communication whereas the uncertainty regarding the place of the discipline is reflected by our hesitation in situating communication within the framework of social sciences, or within social-human sciences or within exact sciences. This is due to the fact that the discipline is not certainly considered as an academic discipline pertaining to humanities, or as social science or as exact science; nothing consensual has been decided yet. Moreover, the discipline's object of study is endowed with a variable geometry. Vlăduţescu (2014: 19-31) argues that the discipline does not possess a thoroughly functional ontological configuration and he contends that this uncertainty does not only uncover an ontological crisis that could be remedied, but also the possibility to solve this issue by identifying a series of identity criteria, as well as by consolidating the discipline on internal level, before imposing and promoting it externally. In order to solve this uncertainty, we have to ask ourselves how communication is directly or indirectly considered by other disciplines (Voinea, 2011; Strunga \& Bunaiasu, 2013; Islam, Cojocaru, Siti Hajar, Wahab \& Sulaiman, 2014).

Last, but not least, the uncertainty concerning the dichotomy unification-fragmentation tackles the constant attempt to unify the discipline so that it becomes powerful and more rigorous in spite of the continuous fragmentation of the discipline into micro-specialties such as: intercultural communication, interpersonal communication, non-verbal communication, verbal communication, visual communication, anthropology of communication, psychology 
of communication, sociology of communication and so on. Vlăduţescu (2013: 29) acknowledges that this uncertainty can be solved by accepting the paradox of the discipline: it is situated against the current - that is while social sciences in general are subject to a constant process of fragmentation and fissuring, communication aims to achieve unification, no matter how hard the efforts might be. It is possible, he asserts, that this issue be fought against through the unconstrained analytical unification and through the axialisation of the space of communication according to a set of axes or convergent criteria (Bulgaru-Iliescu, Oprea, Cojocaru \& Sandu, 2013; Smarandache \& Vladutescu, 2014).

In this paper, we concentrated on two of the above mentioned uncertainties, the title uncertainty and the uncertainty concerning the place of the discipline, by analyzing how these uncertainties of communication as academic discipline are tackled in the virtual environment. In order to do so, we used the comparative citation analysis on a corpus of study constituted by sixteen titles of books in Italian and sixteen titles of publications in Spanish, both representative for the domain of science of information and communication and published in the last twenty years in two different cultural and scientific areas (Italian and Spanish) and we examined the frequency, patterns, the labels and graphs of citation of these publications in six electronic specialist bookshops - three Italian electronic bookshops and three Spanish electronic bookshops.

We employed a comparative statistical analysis of the categories and scientific domains these publications are included and comprised in on the virtual platforms as to uncover the above mentioned uncertainties and at the end, we will propose a model for the standardization of domain categories and tags of the same title on several bookshop sites.

\section{A COMPARATIVE CITATION ANALYSIS OF PUBLICATIONS IN ITALIAN AND SPANISH ELECTRONIC BOOKSHOPS}

\subsection{A study on the Italian corpus}

As we have previously noticed, we first applied the comparative citation analysis on a corpus of study constituted by sixteen titles of books in Italian, representing reference publications for the domain of science of information and communication and published in the last twenty years; on this corpus, we analyzed the frequency, patterns, the labels of citation of these publications as well as the pertinence of these labels in three Italian electronic bookshops: www.ibs.it, www.inmondadori.it, www.hoepli.it

On initial consideration, we observe that some books quoted on the virtual platform of the bookshops are rightly labeled within the domain of communication, while others are classified on multiple levels or categories which do not include communication at all. The frequency of patterns and association of labels with the main topic of each of these books augment the degree of uncertainty regarding the place they occupy and the framework of scientific domains within which they are comprised.

In order to better grasp the two uncertainties, we have formulated a way of associating values of certainty to the books that are quoted in the three Italian virtual bookshops, books which are tagged according to filters, related categories, domains and related subjects. Our aim is to measure with which degree we have the certainty to find for a selected book on our corpus the right associated category Communication/Communication studies 
Here is a model for associating values to the specific books and their titles, all those included in the Italian corpus. We will also use this pattern for associating values for the analysis on the Spanish corpus:

\begin{tabular}{|c|c|}
\hline $\begin{array}{c}\text { Position of the } \\
\text { category }\end{array}$ & $\begin{array}{c}\text { Associated } \\
\text { value }\end{array}$ \\
\hline 1 out of 5 & 1 \\
\hline 2 out of 5 & $4 / 5$ \\
\hline 3 out of 5 & $3 / 5$ \\
\hline 4 out of 5 & $2 / 5$ \\
\hline 5 out of 5 & $1 / 5$ \\
\hline
\end{tabular}

The general pattern of association of values reads as follows: if we have $p$ categories and the category Communication/Communication Studies finds itself on $i$ position, then the certainty for us to find a book from the corpus labeled in the category Communication/Communication Studies has the value $\frac{p-i+1}{p}$.Consequently, we obtain the following table:

\begin{tabular}{|c|c|}
\hline $\begin{array}{c}\text { Position of } \\
\text { the category }\end{array}$ & $\begin{array}{c}\text { Associated } \\
\text { value }\end{array}$ \\
\hline 1 out of $\mathrm{p}$ & $\mathrm{p} / \mathrm{p}=1$ \\
\hline 2 out of $\mathrm{p}$ & $(\mathrm{p}-1) / \mathrm{p}$ \\
\hline$\ldots$ & $\ldots \ldots$ \\
\hline i out of $\mathrm{p}$ & $(\mathrm{p}-\mathrm{i}+1) / \mathrm{p}$ \\
\hline$\ldots$ & $\ldots$ \\
\hline $\mathrm{p}-1$ out of $\mathrm{p}$ & $2 / \mathrm{p}$ \\
\hline $\mathrm{p}$ out of $\mathrm{p}$ & $1 / \mathrm{p}$ \\
\hline
\end{tabular}

For example, if we choose book number 2 (La comunicazione interculturale) from the first virtual bookshop (www.ibs.it) (see Annexes), the way of calculating the value will be the following: in the electronic bookshop ibs.it, book number 2 (b2) is cited and labeled in three different categories according to the pertinence of its subject topic. The book is thus labeled in three categories and domains, yet the third category which is listed on the platform for the book citation is relevant for its main domain of study - communication studies. The other two categories, which precede the third manner of categorization of the book, framework it in within other domains of study such as: Society, politics... and Interdisciplinary Studies. So, if for book b2 from the first bookshop in our Italian corpus there are quoted three categories, and for book b2 we discover the filter/domain which is the most relevant to the subject topic and domain of study - communication in category 3 , we associate with the book title the certainty value calculated using the previous formula $(3-3+1) / 3=1 / 3 \approx 0.33$. So, if we discovered the most relevant filter/domain (Communication) on the $3^{\text {rd }}$ position out of 3 categories, then we would attach to it the value $1 / 3$, and if the relevant filter/category were on the $2^{\text {nd }}$ place out of 3 categories, we would associate to it the value $2 / 3$, if it were on the $1^{\text {st }}$ place out of 3 categories, we would associate the value 1 . 
In the tables below, we have rendered the values of certainty and uncertainty relating to the higher or lower degree of correspondence between the main subject matter of each book and the category/scientific domain within which the subject matter of the book is subsumed.

\begin{tabular}{|c|c|c|c|}
\hline \multicolumn{5}{|c|}{} & $\begin{array}{c}\text { Bookshop1 } \\
\text { Ibs.it }\end{array}$ & $\begin{array}{c}\text { Bookshop2 } \\
\text { Mondadori }\end{array}$ & $\begin{array}{c}\text { Bookshop3 } \\
\text { Hoepli }\end{array}$ \\
\hline \multicolumn{5}{|c|}{ CERTAINTY } \\
\hline b1 & 0 & 0 & 0 \\
\hline b2 & 0.33 & 0 & 0.33 \\
\hline b3 & 0 & 0 & 0.33 \\
\hline b4 & 0 & 0 & 0 \\
\hline b5 & 0 & 0 & 0.33 \\
\hline b6 & 0.33 & 0 & 0.66 \\
\hline b7 & 0.33 & 0.33 & 0.33 \\
\hline b8 & 0 & 0 & 0.33 \\
\hline b9 & 0 & 0 & 0 \\
\hline b10 & 0.33 & 0 & 0.33 \\
\hline b11 & 0 & 0 & 0 \\
\hline b12 & 0 & 0 & 0.66 \\
\hline b13 & 0 & 0 & 0.66 \\
\hline b14 & 0.33 & 0 & 0 \\
\hline b15 & 0.33 & 0 & 0 \\
\hline b16 & 0.29 & 0 & \\
\hline & & & 0 \\
\hline
\end{tabular}

In order to measure place uncertainty, we can use the formula of calculation for the Herfindahl index:

$$
H=\sum_{i=1}^{n} p_{i}^{2}
$$

where $p_{i}$ is probability that the book $b_{i}$ exists in the Bookshop1 and is associated to the category Communication/Communication studies.

Also, the Herfindahl index can be an indicator of the amount of competition among the identified categories. Increases in the Herfindahl index generally indicate a decrease in competition among categories. The major benefit of the Herfindahl index in relationship to such measures as the concentration ratio is that it gives more weight to larger and more general categories.

In our case, starting from data from the table above, for Italian Bookshop1 we obtain

$$
H=\sum_{i=1}^{16} p_{i}^{2}=\frac{6 \cdot 0.33^{2}+0.29^{2}}{16^{2}}=\frac{0.7375}{256}=0.0029,
$$

and for Bookshop2 we have 


$$
H=\sum_{i=1}^{16} p_{i}^{2}=\frac{6 \cdot 0.33^{2}+3 \cdot 0.66^{2}}{16^{2}}=\frac{1.9602}{256}=0.0077
$$

These values are compared with the value $1 / 16=0.0625$ when probabilities are equal. This indicates a stronger competition among categories for book topics in Italian bookshop 3 and a weaker competition in Italian Bookshop1.

While drawing a comparison between the levels of uncertainty registered in each of the virtual bookshops, we discover that Internet Bookshop Italia's electronic platform includes books' citation indices which enable the navigator to rightly categorize and label the books as being comprised within the larger domain of communication/communication studies/media\& communication(s). $43 \%$ of the books included in our corpus of study are labeled using patterns that allow the navigator, potential reader and buyer, to correctly frame the subject matter of each book within the spectrum of communication. Hoepli's electronic bookshop uses filters and tags for the categorization of each book into specific categories, yet its uncertainty is $13 \%$ lower than on Internet Bookshop Italia.

Even if for book title no 13, Teoria e tecniche della comunicazione pubblica, Internet Bookshop's software produces no more than four filters for the domain within which the subject matter of the book is confined: economics and management; management; administration and administration techniques; administration of specific areas, automatic categorization remains imprecise for it hides the specific communicational content of the book. Unlike Internet Bookshop, Hoepli's electronic platform employs an operating system for the generation of automatic categorization that is more precise, even though it generates a narrower range of filters for the subject matter of the book. On this platform, the book's main topic is rightly circumscribed within the domain Media and Communication, even though this domain is considered as a hyponym to the hyperonymic category Economics, marketing, finance and management.

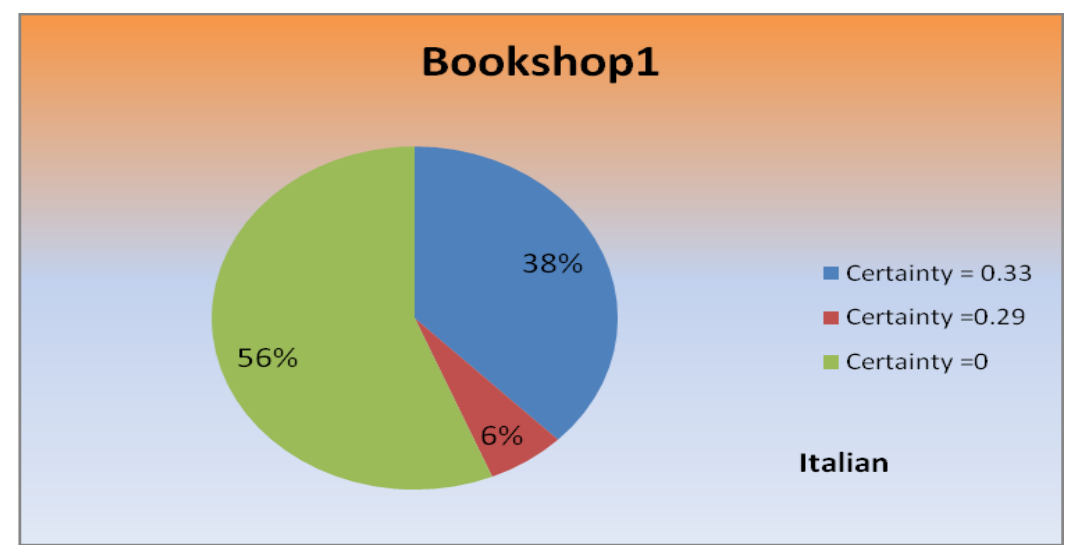

A weakness of Mondadori's software that was designed in order to automate the process of adding Subject metadata for the products on its virtual market is that of making use of another module built into it to list the books, cite them and classify them with taxonomies that would fall under related labels or larger categories within which communication is included (such as Interdisciplinary and Cultural Studies, Politics and Society); the categories are not strictly assigned to a specific book title and to its subject matter, on the contrary, they relate to several results obtained after entering the title of one book onto the site's searching engine and the generation of quite a few findings more or less 
pertinent or connected to the title and subject of the book a navigator is looking for (as is the case with Il linguaggio segreto del corpo. La comunicazione non verbale by Anna Guglielmi). Therefore, the related categories are not $100 \%$ associated to the specific subject matter of the book, but they are connected to all the books whose title or labels resemble in a lower or higher degree to that of Il linguaggio segreto del corpo. La comunicazione non verbale and in this case, the related fields are Psychology and Philosophy. That is why Mondadori's percentage of uncertainty is the highest of all three electronic bookshops, 94\%, and we suggest that changes and improvements be operated on its categorization software so as to convey wider book labeling and citation capabilities.

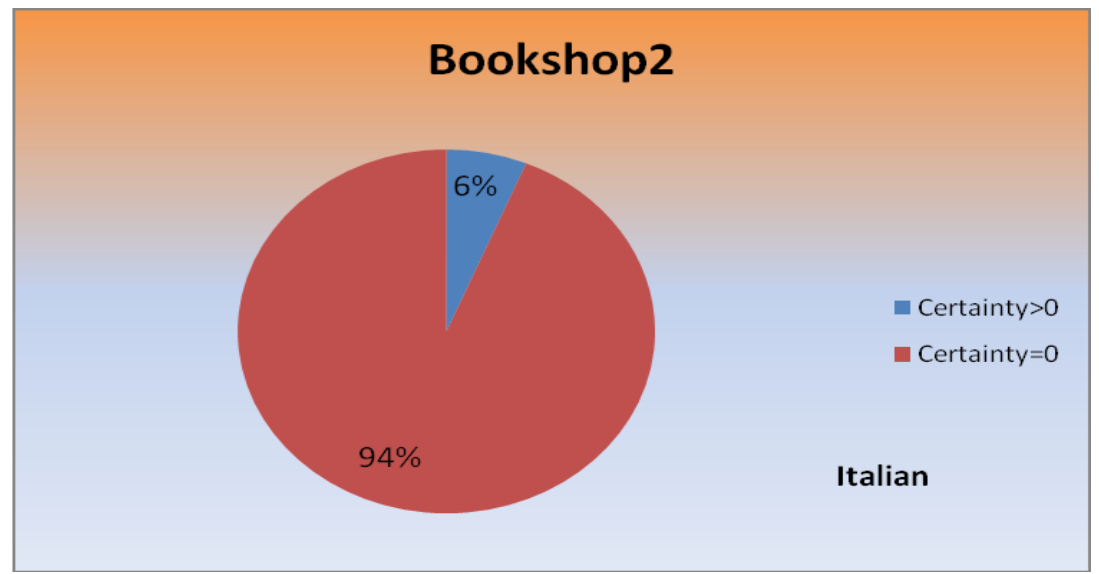

With the three Italian electronic bookshops, the level of uncertainty registered following the automatic categorization of book titles and their subject matters rises to $65 \%$.

We can also draw the attention to Internet Bookshop's inconsistency in categorizing two books whose similar contents should assign them to the same domain when we discover that La comunicazione non verbale is circumscribed to the domain psychology, psychoanalysis, the same as with Hoepli, whereas Il linguaggio segreto del corpo. La comunicazione non verbale is framed within the categories Self-help and Health, family and personal well-being, even though both books have similar subject matters. Another inadvertence with ibs.it is reflected by the misplacing of two books whose main topic is public communication within the domain Economics and Management.

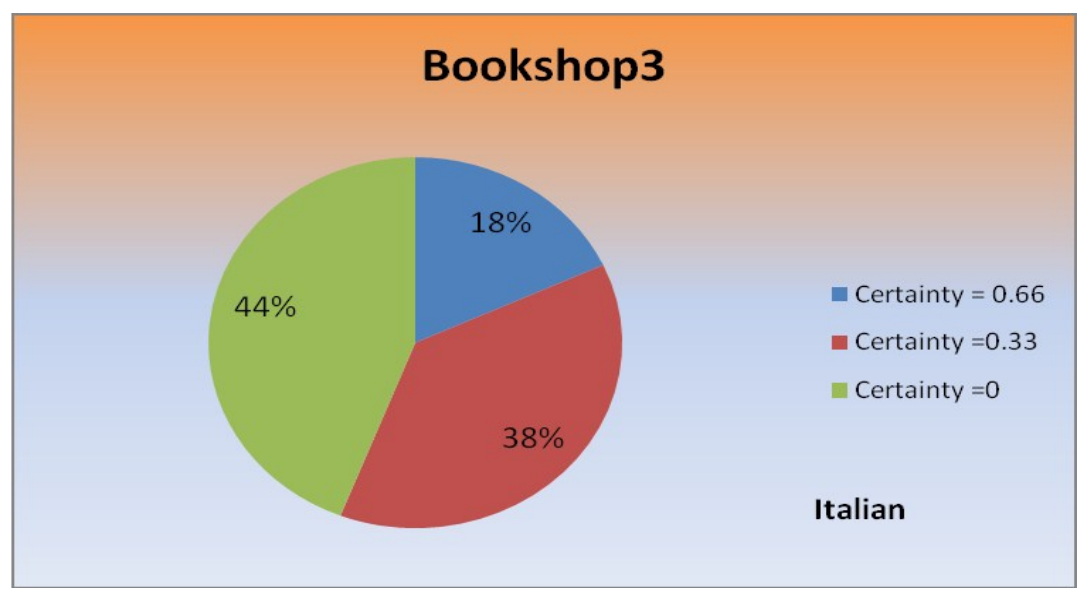

Considering the uncertainty regarding the place that communication occupies within the spectrum of sciences, social sciences and so on, the comparative citation analysis and the 
comparative statistical analysis of the categories and scientific domains in which these publications are included and comprised on the virtual platforms unveil not only a high level of confusion and hesitation when classification of one or more book titles is performed, but also that taxonomies are listed and automatically generated by the application software so as to reveal the indiscipline and the irresolution in bestowing a clear place or scientific area within which the book's study object might be circumscribed. The uncertainty concerning the place of the discipline within the spectrum of larger domains of study/sciences is reflected at triple level and revealed by the fact that: 1) the discipline, as well as the books' titles and their subject matters are not registered with certainty neither within the framework of social and human sciences, nor within Sociology and Anthropology; 2) a book's contents might be related to more than one subject matter, so that its object of study might at the same time be connected to philosophy and ethics (see categorization of book title no 4 on ibs.it) or to psychology and communication (see categorization of book title no 3 on hoepli.it); 3 ) the categorization engine used on these platforms, especially in Mondadori's virtual shop, does not have a thoroughly functional configuration. Its flaws or weaknesses might be corrected by identifying a series of pertinent taxonomic identity criteria, which do not conceal the communicational content of publications.

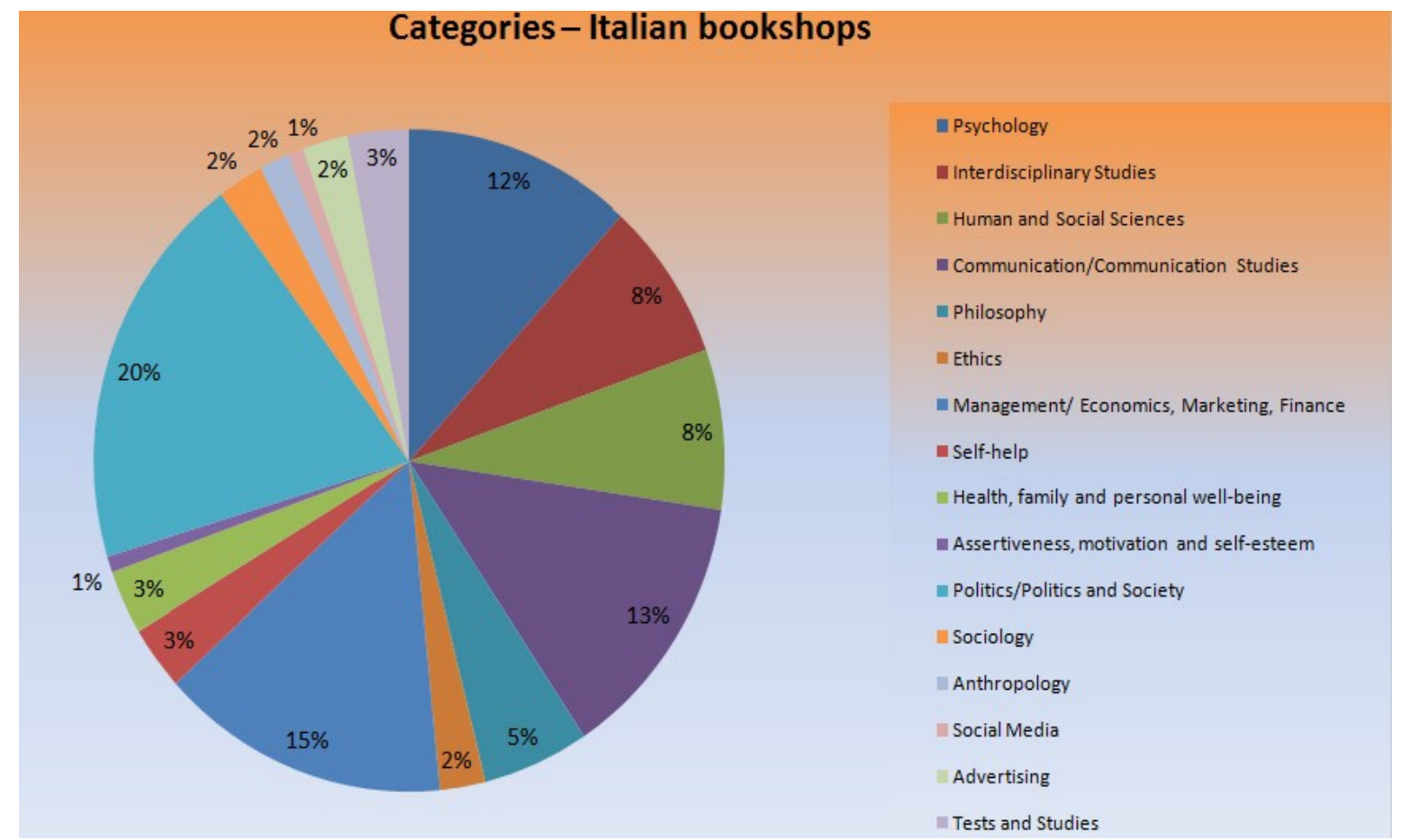

Before interpreting the data from the chart above, we can calculate place uncertainty for categories encountered in Italian bookshops using the Herfindahl index formula and we get

$$
H=2 \cdot 0.01^{2}+4 \cdot 0.02^{2}+3 \cdot 0.03^{2}+0.05^{2}+2 \cdot 0.08^{2}+0.12^{2}+0.13^{2}+0.15^{2}+0.20^{2}=0.112
$$

It is interesting to notice that the value of the Herfindahl index for categories within which book topics are included in Italian bookshops is equal to the value of the Herfindahl index for categories in Spanish bookshops, even though Italian bookstores employ a software 
program that automatically generates richer categorization filters for the domains within which the subject matters of the books are circumscribed.

On the Italian virtual platforms, the first level at which the uncertainty concerning the place of the discipline within the spectrum of larger domains of study/sciences is disclosed would read such as follows: $13 \%$ of the book titles and their study objects are tagged within the category Communication/ Communication studies/Communication and Media, 8\% are placed within the framework of human and social sciences, $20 \%$ are included in the larger domain: Politics/Politics and Society, $15 \%$ are labeled in Management/ Economics, Marketing, Finance and Management, $8 \%$ are included in the category Interdisciplinary Studies/ Interdisciplinary and Cultural Studies, 12\% are circumscribed to Psychology, 5\% are related to Philosophy and 2\% to Ethics, $1 \%$ are subsumed to Social Media - which might be considered as a hyponymic category subordinated to the hyperonymic category Media and Communication - while 3\% are strangely related to Self-Help, 2\% to Health, family and personal well-being, $1 \%$ to Assertiveness, motivation and self-esteem; $2 \%$ are subordinated to Sociology, even though communication is not a hyponym to the hyperonym Sociology, $2 \%$ are confined within the domain of Anthropology, $2 \%$ are comprised within the discipline Advertising and 3\% are linked to the category Tests and studies.

The most evident confusion is in subsuming the subject matters of these books to other disciplines that are included within the spectrum of social sciences, disciplines with which communication has in common several research methods and techniques, but which are not, in any case, a hyperonym to a hyponymic class - communication (most often than not, on the Italian virtual platforms, Communication appears as a categorization label for book titles and their contents thought of as a hyponym to the hyperonymic category - Psychology, even though Communication and Psychology represent two distinct social sciences and disciplines, whereas Communication and Media is considered as a categorization label for book titles and their contents thought of as a hyponym to the hyperonymic category - Economics, Marketing, Finance and Management).

Tackling the uncertainty regarding the place that communication occupies within the spectrum of sciences, social sciences and so on, we become aware that the results of the comparative statistical analysis of the categories and scientific domains the publications are included in on the virtual platforms ibs.it, inmondadori.it, hoepli.it reflect the fact that several book titles and subject matters are confined and misplaced within the domain of Psychology and Economics and Management, in spite of their communicational contents.

When the labeling patterns are applied to books on Internet Bookshop's platform, subject matters of books relating to communication or a specific type of communication (such as non-verbal communication or public communication; see book titles no 8 and 13) are placed within a section or a shelf where they are considered as a hyponymic category of the hyperonym Psychology and Economics, Marketing, Finance and Management.

The fact that most of the times, subject matters of books mainly relating to communication studies are mistagged within the domain of Psychology on ibs.it and inmondadori.it could be somehow justified by the fact that communication as a discipline has four certain sources: Sociology, Psychology, Anthropology, and Rhetoric, according to Robert T. Craig (1999). The author acknowledges these to be the four traditions of communication or axes of communication. Even taking into account R.T. Craig's argumentation that justifies the utility of a Traditions Standard-Matrix for communication, we contend that communication has developed, evolved, extended and hence, was able to separate and leave the territory of Sociology, Psychology, Anthropology and Rhetoric, imposing itself as an independent science and field of study. 
One last remark that needs to be made is that confusion occurs when the software for automatic categorization employed by inmondadori.it remains imprecise and hesitates in how to label a series of books in a certain category; that is why more than $12 \%$ of the books' topics on this platform are simply tagged as "Italian books" and thus does not help to classify subject matters in several domains or fields of study.

\subsection{A study on the Spanish corpus}

Our next step was to apply the comparative citation analysis on a corpus of study constituted by sixteen titles of books in Spanish, representing reference publications for the domain of science of information and communication and published in the last sixteen years; on this corpus, we identified the frequency, patterns, the labels of citation of these publications as well as the relevance of these labels in three Spanish electronic bookshops: www.casadellibro.com, www. ocio.elcorteingles.es/libros, www.iberlibro.com.

\begin{tabular}{|c|c|c|c|}
\hline & $\begin{array}{c}\text { Bookshop1 } \\
\text { Casa del Libro }\end{array}$ & $\begin{array}{c}\text { Bookshop2 } \\
\text { El Corte Inglés }\end{array}$ & $\begin{array}{c}\text { Bookshop3 } \\
\text { Iberlibro }\end{array}$ \\
\hline & \multicolumn{3}{|c|}{ CERTAINTY } \\
\hline b1 & 0 & 0 & No relevant domain \\
\hline b2 & 0.5 & 0 & No relevant domain \\
\hline b3 & 0 & 0 & No relevant domain \\
\hline b4 & 0.66 & 0 & No relevant domain \\
\hline b5 & 0 & 0 & No relevant domain \\
\hline b6 & 0.66 & 0 & No relevant domain \\
\hline b7 & 0 & 0 & No relevant domain \\
\hline b8 & 0 & 0 & No relevant domain \\
\hline b9 & 0 & 0 & No relevant domain \\
\hline b10 & 0 & 0 & No relevant domain \\
\hline b11 & 0.66 & 0 & No relevant domain \\
\hline b12 & 0.66 & 0 & No relevant domain \\
\hline b13 & 0.66 & 0 & No relevant domain \\
\hline b14 & 0.66 & 0 & No relevant domain \\
\hline b15 & 0.66 & 0 & No relevant domain \\
\hline b16 & 0.66 & 0 & No relevant domain \\
\hline
\end{tabular}

The same formula is used for the calculation of the degree of uncertainty as with the Italian corpus. The degree is uncertainty is calculated by using the formula 1 - degree of certainty. While measuring the level of certainty registered for the entry of each book in our Spanish corpus on each of the three virtual platforms, we deduce that the value associated with it for one or another of the book titles in the Spanish corpus is indirectly proportional with the number of existing positions or categories within which the contents of the book is subsumed. The higher the number of positions, the lower the degree of certainty becomes.

In order to measure place uncertainty, we can also use the formula of calculation for the Herfindahl index we used for the Italian corpus: 


$$
H=\sum_{i=1}^{n} p_{i}^{2} .
$$

Used in the same manner so as to represent an indicator of the amount of competition among categories, in this case, starting from data from the table above, the Herfindahl index is calculated such as follows

$$
H=\sum_{i=1}^{16} p_{i}^{2}=\frac{0.5^{2}+8 \cdot 0.66^{2}}{16^{2}}=\frac{3.7348}{256}=0.014589 \text {. }
$$

As we have already mentioned, this value is compared with the value $1 / 16=0.0625$ when probabilities are equal. This indicates a weak competition among categories in Spanish bookshop 1 (Casa del Libro).
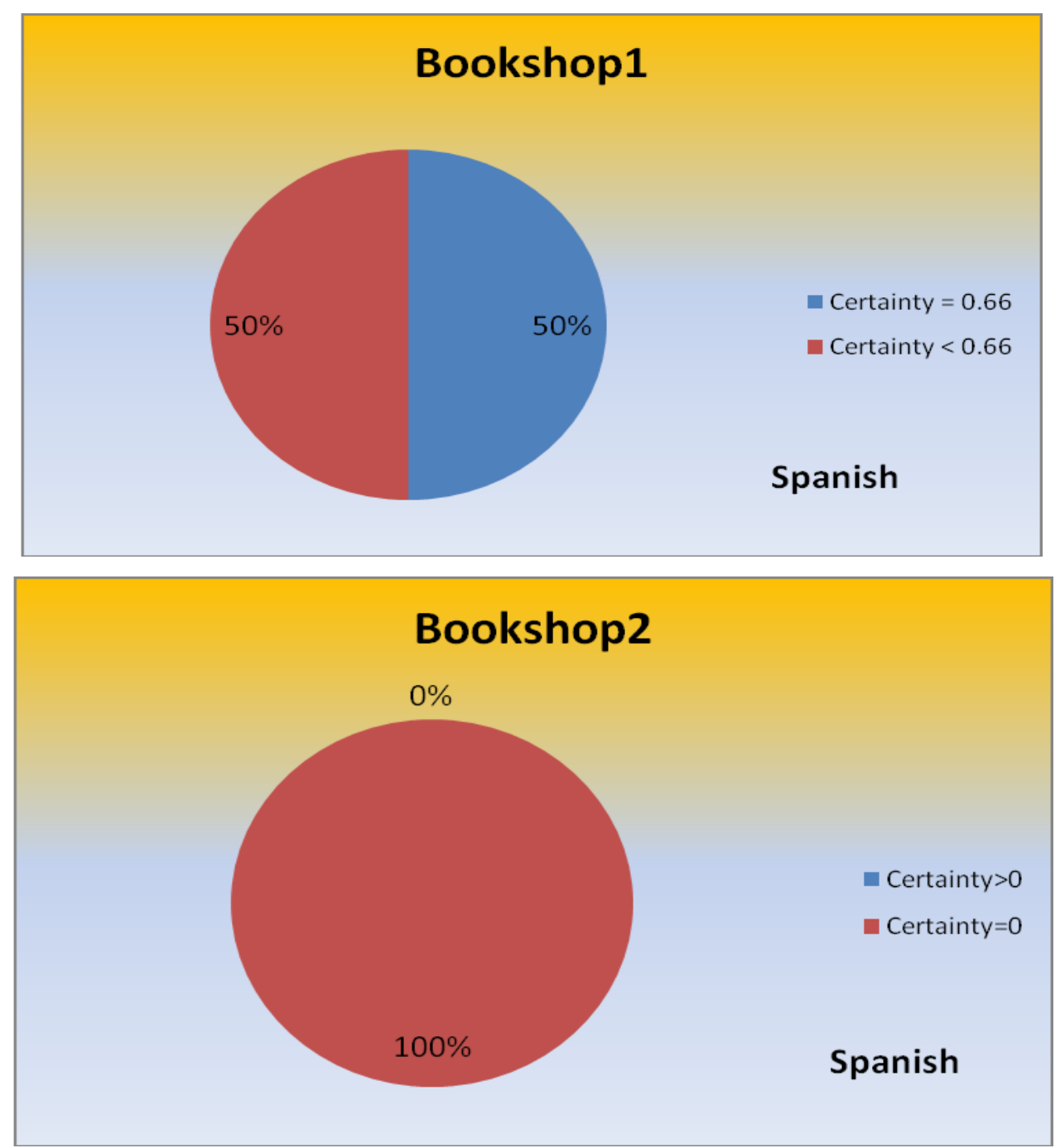

Looking at the results of the comparative citation analysis and of the comparative statistical analysis of the categories and scientific domains in which these publications are included and comprised on the three Spanish virtual platforms, we understand that these do not only convey a high degree of ambiguity and irresolution when taxonomies of domains are 
automatically generated and listed by the software, but also that the richer the taxonomies for categorization and organization on bookshops' sites get, the list is still not complete.

Even though Casa del Libro's platform is empowered by a software program which develops taxonomies dedicated to the classification of book titles and their contents in accordance with their differences and similarities within specific areas or scientific domains, its categorization module is unlikely to be all comprehensive. In spite of a small-to-medium number of categories it generates and acknowledges for each book title and subject matter, it still remains inaccurate, unprecise. The higher the number of positions and categories Casa del Libro's software generates for each product, the higher the level of uncertainty gets; as we can notice from the following charts, its filters are able to discriminate amongst a variety of categories, but enable the labeling of the book title and of its subject matter within the domain of communication in half of the cases. Therefore, it does not only obnubilate the communicational content of publications chosen in our corpus of study, but it also measures $50 \%$ in our uncertainty calculation. As opposed to Casa del Libro, El Corte Inglés and Iberlibro have software programs that generate a poorer and much simpler taxonomy for categorization and organization of book titles, which does not prove to be more accurate when framing the book contents within a major domain or field of study. The level of uncertainty with El Corte Inglés is $100 \%$, whereas Iberlibro employs a categorization software which does not acknowledge any relevant domain within which the book topics can be confined.

Uncertainty emerges from the number of variables (categories and domains) involved and from the relations between them. It is also illustrated by the constant oscillation between domains while trying to perform the localization of the discipline communication, but also of the book titles and their topics within the range of sciences/social sciences or other disciplines and fields of study. We observe the alternation between psychology and communication, while comparing the tagging patterns of the book Enciclopedia de la communicación and Teoria de la comunicación social on casadellibro.com. We can thus draw the attention to Casa del Libro's inconsistency in categorizing two books whose relatively similar contents and metalanguage should assign them to the same domain when we discover that Enciclopedia de la communicación is circumscribed to the domain comunicación (communication) whereas Teoria de la comunicación social is framed within the category psicologíal psicología y pedagogía social (psychology/psychology and social pedagogy), even though both book topics should be integrated within the field communication/communication studies. Another inadvertence with Casa del Libro is reflected by the misplacing of a book whose main topic is non-verbal communication (La otra comunicación. Comunicación no verbal) within the domain The Firm/ Administration and company management and of a book about crisis communication (Comunicación de crisis) within the domains: economics and marketing \& advertising. The high level of uncertainty with El Corte Inglés is illustrated by the categorization taxonomies which its software lists and automatically generates so that they reflect the irresolution in alloting a clear place within which the study object of a referential book for the theory of communication might be delimited; the subject matter of the book Teoria de la comunicación social is subsumed to the belletristic genre, even if it is not a novel or a story it pertains to. 


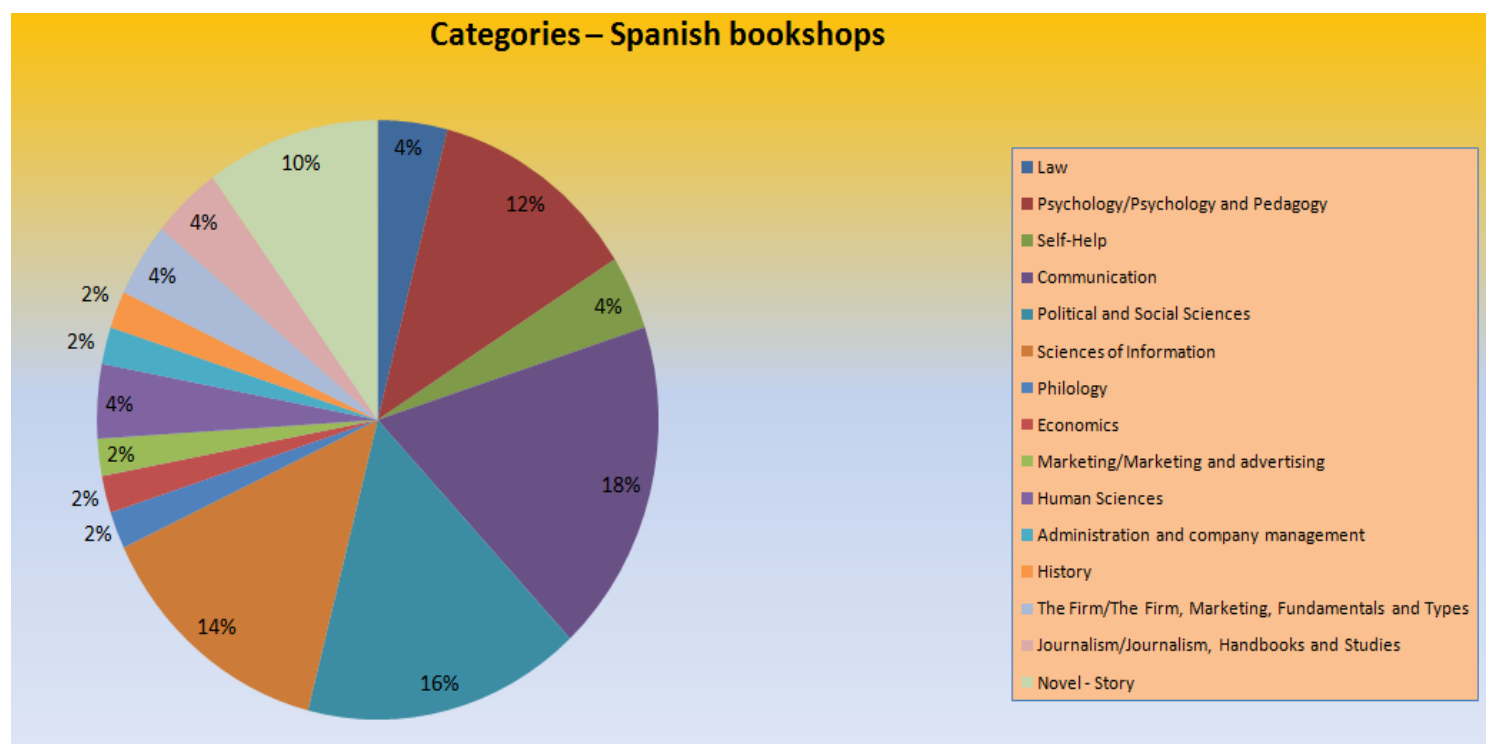

Before interpreting the data from the chart above, we can calculate place uncertainty for categories encountered in Spanish bookshops using the Herfindahl index and we obtain

$$
H=\sum_{i=1}^{16} p_{i}^{2}=5 \cdot 0.04^{2}+5 \cdot 0.02^{2}+0.1^{2}+0.12^{2}+0.14^{2}+0.16^{2}+0.18^{2}=0.112
$$

This value is compared with the value $1 / 16=0.0625$ when probabilities are equal. This indicates a weak competition among categories.

As far as the uncertainty regarding the place of the discipline within the spectrum of larger domains of study/sciences is concerned, this reads such as follows: $18 \%$ of the book titles and their study objects are tagged within the category Communication, $16 \%$ are placed within the framework of Political and Social Sciences, $4 \%$ are confined within the spectrum of Journalism, $4 \%$ are labeled in Human Sciences, $12 \%$ are included in the category Psychology or Psychology and Pedagogy, $4 \%$ are circumscribed to Law, 14\% are subsumed to Sciences of information- which represents a hyperonymic category for classification while $4 \%$ are strangely related to the Firm (The Firm, Marketing. Fundamentals and Types), $2 \%$ are concerned with Administration, $2 \%$ relate to Marketing and Advertising and 2\% to History, while another $2 \%$ are connected to Philology, 2\% to Economics and 4\% cover the category "Self-Help". A tenth of the books' subject matters are completely mistagged, since the software for automatic categorization employed by El Corte Inglés generates a seemingly divergent category framing the subject topics of the books within the belletristic genre. A referential book such as Teoria de la comunicación social is thus mislabeled in the category Novel-Story. Another conspicuous mistake happens when the subject matters of these books are subsumed to other disciplines (in particular, psychology) that are included within the spectrum of social sciences, disciplines with which communication has in common several research methods and techniques, but with which communication is never to be confounded. 
From the comparative analysis of the bookshops, we notice that the most significant Spanish online bookstore is Casa del Libro. This has a functional categorization software that produces several filters for the domains within which the topic of the book is encompassed. Unlike Casa del Libro, the online bookstore of El Corte Inglés employs a poorly developed categorization software which does not help to recognize and classify the subject topic of any of the referential books for the domain of science of information within the right field (Communication or Communication Studies). In fact, it merely discriminates between one or two domains/categories and most often than not (in more than $30 \%$ of the cases) wrongly confines the topics of the scientific books within the belletristic genre, even though not even one of the titles is that of a novel or of a story. The third Spanish online bookshop selected in our corpus of study functions on the basis of a categorization software that does not acknowledge any relevant domain within which the book topics can be circumscribed; tags for description on this site include only bibliographical data: title, author, condition of the book, price and transport expenses. Other electronic bookstores from Hispanophone countries use a tagging software that does not discriminate any category, domain or genre for the books they sell. Most of the links to these sites are not functional or the sites are under current work of maintenance (http://www.celesa.es/home.htm, ttp://www.porrua.com.mx/index2.html, http://libreria.interbook.net/BusquedaTematica.asp, $\quad$ http://www.j-libros.com/, http://www.lsf.com.ar/, $\quad$ http://www.gandhi.com.mx/cgi-bin/gandhi.storefront, http://www.elsotano.com.mx/, http://www.tematika.com.ar/)

Another observation that needs to be expressed is that the uncertainty regarding the title of the discipline is reflected on both corpuses of study where title instability is registered for the two different cultural and scientific areas.

There is a set of denominations associated with the body of knowledge about communication. For the discipline whose epistemic object is communication we discover many titles in both areas in our corpuses: "ciencia de la información", "ciencias de la comunicación", "teoría de la comunicación", "comunicación", "studi sulla comunicazione", "comunicazione", "teoria della comunicazione", "teoria e tecnologia della comunicazione", "scienze della comunicazione", "scienze dell'informazione, della comunicazione e dell'editoria".

At a compared approach of the management of denominations and of title uncertainty for the discipline communication in the two cultural-scientific areas, we notice that while in the Italian field, "communication studies" and "sciences of information, communication and publishing" are preferred, in Spanish and Hispanophone areas, there is favoured the title "science of information" alongside with the teaching of "the theory of communication" in the higher education system. Whereas Spanish theorists favour the use of "teoría de la comunicación"/theory of communication (Jose Luis Piñuel Raigada (1997), Manuel Martin Serrano (2007)), or "teoría de la información y de la comunicación/theory of information and communication (Julio Cesar Herrero (2009)) and "science of information" (Luis Jesus Galindo Caceres (2008), Italian researchers impose the employment of "scienze della comunicazione"/sciences of communication (Mario Morcellini, Giovambattista Fatelli, (1994)) and "teoria della comunicazione"/theory of communication (Lorena Patacchini (2013), Rolando Stefano (2011)).

At the end of the study, we propose a model for the standardization of domain categories and tags of a book title when accessing information about the book on several electronic bookshop sites. 


\section{A STANDARDIZATION MODEL FOR MANAGING THE TWO UNCERTAINTIES}

We will consider and note with $n$ the number of years submitted to study, that is $A_{1}$ for the first year taken into consideration and so on, $A_{1}, A_{2}, \ldots, A_{n}, m$ - the number of electronic bookshops, that is $L_{1}$ for bookshop $1, L_{2}$ for bookshop 2 and so on $-L_{1}, L_{2}, \ldots, L_{m}, q$ - the number of books that are subject to our research, that is $c_{1}, c_{2}, \ldots, c_{q}$ and $p$ - the number of domains or categories within which the books and their contents are included, that is $D_{1}, D_{2}, \ldots, D_{p}$.

Given the table in which we examine the fact that a book $c_{k}$ is found in bookshop $L_{i}$ during the year $A_{j}$ :

\begin{tabular}{|c|c|c|c|c|}
\hline & $A_{1}$ & $A_{2}$ & $\ldots$ & $A_{n}$ \\
\hline$L_{1}$ & $a_{11}$ & $a_{12}$ & $\ldots$ & $a_{1 n}$ \\
\hline$L_{2}$ & $a_{21}$ & $a_{22}$ & $\ldots$ & $a_{2 n}$ \\
\hline$\ldots$ & $\ldots$ & $\ldots$ & $\ldots$ & $\ldots$ \\
\hline$L_{m}$ & $a_{m 1}$ & $a_{m 2}$ & $\ldots$ & $a_{m n}$ \\
\hline
\end{tabular}

where the fact that a book $c_{k}$ is to be found in the electronic bookshop $L_{i}$ in the year $A_{j}$ is written in the following way: $c_{k} \in L_{i} \wedge A_{j}$, and if a book $c_{k}$ is not to be found in the bookshop $L_{i}$ in the $A_{j}$ is written in the following manner: $c_{k} \notin L_{i} \wedge A_{j}$, and

$$
a_{i j}=\left\{\begin{array}{lll}
1, & \text { dac } \breve{a} & c_{k} \in L_{i} \wedge A_{j} \\
0, & \text { dac } \breve{a} & c_{k} \notin L_{i} \wedge A_{j}
\end{array}\right.
$$

given the table in which we analyze the fact that a book $c_{k}$ is placed in the year $A_{i}$ within the domain/category $D_{j}$ :

\begin{tabular}{|c|c|c|c|c|}
\hline & $D_{1}$ & $D_{2}$ & $\cdots$ & $D_{p}$ \\
\hline$A_{1}$ & $b_{11}$ & $b_{12}$ & $\cdots$ & $b_{1 p}$ \\
\hline$A_{2}$ & $b_{21}$ & $b_{22}$ & $\cdots$ & $b_{2 p}$ \\
\hline$\ldots$ & $\ldots$ & $\ldots$ & $\ldots$ & $\ldots$ \\
\hline$A_{n}$ & $b_{n 1}$ & $b_{n 2}$ & $\cdots$ & $b_{n p}$ \\
\hline
\end{tabular}

where the fact that a book $c_{k}$ is found during the year $A_{i}$ in the domain $D_{j}$ is written in the following way: $c_{k} \in A_{i} \wedge D_{j}$, and if a book $c_{k}$ is not found during the year $A_{i}$ in the domain $D_{j}$ is written such as follows: $c_{k} \notin A_{i} \wedge D_{j}$; 


$$
b_{i j}=\left\{\begin{array}{lll}
1, & \text { dacă } & c_{k} \in A_{i} \wedge D_{j} \\
0, & \text { dacă } & c_{k} \notin A_{i} \wedge D_{j}
\end{array} .\right.
$$

therefore, we would associate to the book $c_{k}$ the following matrices:

$$
\bar{C}_{k}=\left(\begin{array}{cccc}
a_{11} & a_{12} & \ldots & a_{1 n} \\
a_{21} & a_{22} & \ldots & a_{2 n} \\
\ldots & \ldots & \ldots & \ldots \\
a_{m 1} & a_{m 2} & \ldots & a_{m n}
\end{array}\right) \text { and } \overline{\bar{C}}_{k}=\left(\begin{array}{cccc}
b_{11} & b_{12} & \ldots & b_{1 p} \\
b_{21} & b_{22} & \ldots & b_{2 p} \\
\ldots & \ldots & \ldots & \ldots \\
b_{n 1} & b_{n 2} & \ldots & b_{n p}
\end{array}\right)
$$

If we multiply the first line from matrix $\bar{C}_{k}$ by the first column of matrix $\overline{\bar{C}}_{k}$, then we obtain $a_{11} b_{11}+a_{12} b_{21}+\ldots+a_{1 n} b_{n 1}$ which represents the number of appearances of the book $c_{k}$ in the bookshop $L_{1}$ within the domain $D_{1}$. Consequently, by multiplying the line $i$ of matrix $\bar{C}_{k}$ with the column $\mathrm{j}$ of matrix $\overline{\bar{C}}_{k}$, we obtain the element

$$
a_{i 1} b_{1 j}+a_{i 2} b_{2 j}+\ldots+a_{i n} b_{n j}
$$

which represents the number of appearances of the book $c_{k}$ in the bookshop $L_{i}$ within the domain $D_{j}$. All these elements are obtained by the multiplication of matrix $\bar{C}_{k}$ with matrix $\overline{\bar{C}}_{k}$.

Given the matrix $C_{k}=\bar{C}_{k} \overline{\bar{C}}_{k}=\left(c_{(i j) k}\right)_{i=\overline{1, m}, j=\overline{1, p}, k=\overline{1, q}}$, where $c_{(i j) k}=a_{i 1} b_{1 j}+a_{i 2} b_{2 j}+\ldots+a_{i n} b_{n j}$, we can also calculate other values

$$
n-\left(a_{i 1} b_{1 j}+a_{i 2} b_{2 j}+\ldots+a_{i n} b_{n j}\right)=n-c_{(i j) k},
$$

which show us how many times the book $c_{k}$ is found in the bookshop $L_{i}$ in another domain than $D_{j}$.

We can also calculate the probability that the book $c_{k}$ exists in the bookshop $L_{i}$, being tagged within the domain $D_{j}$, and the calculation formula reads such as follows:

$$
p_{k}=\frac{c_{(i j) k}}{n}=\frac{a_{i 1} b_{1 j}+a_{i 2} b_{2 j}+\ldots+a_{i n} b_{n j}}{n} .
$$

Consequently, on a particular case, we must choose the following key-elements: number of years, two, three or more electronic bookshops and identify the domains within which the book titles and their topics are classified. Subsequently, we draw the tables with the respective matrices. A third step would be represented by the analysis of the most relevant indicators or indices, such as the Herfindahl index in order to measure place uncertainty according to the previously mentioned formula 


$$
H=\sum_{i=1}^{n} p_{i}^{2}
$$

where $\sum_{i=1}^{n} p_{i}=1$ and $p_{i}$ is the probability that the book $c_{i}$ exists in a bookshop.

In this model of standardization, we have introduced years and number of years as a key-element, since we observe that for the books present in our corpus of study the categorization domains and labeling patterns were changed from one year to another (as with El Corte Inglés's bookshop), and in order to decrease uncertainty it would be advised for the programmers in charge of site maintenance on these virtual bookshop platforms to create an archive so as to keep track of the changes in the categorization or classification labels of books found on these sites. The programmers can also make use of categorization labels of older versions of a book for labeling a newer version or they can relabel categories for a newer version.

\section{CONCLUSION}

After performing the comparative citation analysis on a corpus of study constituted by thirty-two titles of books representative for the domain of science of information and communication (published in the last twenty years) in two different cultural and scientific areas (Italian and Spanish), and applying the comparative statistical analysis of categories and scientific domains in which these publications are included and comprised on the virtual platforms (three Italian bookshops and three Spanish bookshops), we distinguished the labeling patterns, the graphs of citation and the taxonomies for categorization of book titles and of their subject matters into domains, all of which reflect and are indicators of the existence of two major uncertainties or difficulties: the uncertainty regarding the title of the discipline communication and the uncertainty concerning the place that communication and that books whose subject matters focus on communication occupy within the spectrum of sciences or social sciences or other larger fields of study and domains. Finally, our proposal for a standardization model whose aim was to manage the issues raised by the two difficulties was meant to lower the level of uncertainty and not to conceal it under the mask of a too rigorous or all comprehensive model. In fact, while carrying out his work, a researcher in the domain of communication science should always remains steady amidst doubts, difficulties and surprises and acknowledge that there will always be some uncertainties within his field of study and thereby a limit to calculation, to standardization, to control the uncertainties of communication as academic discipline. To calculate on the uncertain is perhaps the unfathomable and paradoxical operation that this science requires of him.

\section{Acknowledgment}

This work was partially supported by the grant number $33 \mathrm{C} / 2014$, awarded in the internal grant competition of the University of Craiova. 


\section{Corpus}

Italian

Anolli, Luigi (2012). Fondamenti di psicologia della comunicazione. Bologna: Il Mulino.

Balboni, Paolo E. (2007). La comunicazione interculturale. Padova: Marsilio.

Bonaiuto, Marino; Maricchiolo, Fridanna (2009). La comunicazione non verbale. Roma: Carocci.

Fabris, Adriano (2014). Etica della comunicazione. Roma: Carocci.

Di Lauro, Domenico (2011). Manuale di comunicazione assertiva. Milano: Xenia.

Gensini, Stefano (2006). Fare comunicazione. Teoria ed esercizi. Roma: Carocci.

Gili, Guido; Colombo, Fausto (2012). Comunicazione, cultura, società. Brescia: La Scuola.

Guglielmi, Anna (2013). Il linguaggio segreto del corpo. La comunicazione non verbale, Piemme, Milano, 2013.

Mazzoleni, Gianpietro (2012). La comunicazione politica. Bologna: Il Mulino.

Morcellini, Mario; Fatelli, Giovambattista (1994). Le scienze della comunicazione. Modelli e percorsi disciplinari. Roma: Carocci.

Nardone, Giorgio (2013). Correggimi se sbaglio. Strategie di comunicazione per appianare i conflitti nelle relazioni di coppia. Milano: Ponte alle Grazie.

Paccagnella, Luciano (2010). Sociologia della comunicazione. Bologna: Il Mulino.

Rolando, Stefano (2011). Teoria e tecniche della comunicazione pubblica. Milano: Rizzoli Etas.

Tissoni, Francesco (2014). Social network. Comunicazione e marketing. Milano: Apogeo Education.

Tomasello, Michael (2009). Le origini della comunicazione umana. Milano: Cortina Raffaello.

Vecchia, Marco (2003). Hapù. Manuale di tecnica della comunicazione pubblicitaria. Bologna: Lupetti.

Spanish

Azurmendi Adarraga, Ana (2011). Derecho de la comunicación. Barcelona: SA Bosch.

Baro, Teresa (2012). La gran guia del lenguaje no verbal. Barcelona: Paidos Iberica.

Ballenato Prieto, Guillermo (2013). Comunicación eficaz. Madrid: Piramide.

Cantavella, Juan (2012). Enciclopedia de la comunicación, Madrid: Fund. Universidad San Pablo.

De Miguel Pascual, Roberto (2013). Teoria de la comunicación social, Madrid: Centro Estudios Financieros.

Galindo Caceres, Luis Jesus (2008). Comunicación, ciencia e historia, Madrid: McGrow-Hill Interamericana de España.

Jorques Jimenez, Daniel (2012). Comunicación y lenguaje. Valencia: Tirant Humanidades.

Marin, Francisco (2009). Comunicación de crisis. Madrid: LID.

Melendo, Maite (2000). Comunicación e integracion personal. Santander: Sal Terrae.

Minguez Vela, Andres (1999) La otra comunicación. Comunicación no verbal. Madrid: Esic Editorial, Pozuelo de Alarcón.

Pacheco Reda, Martha, Peña Jimenez, Palma (2012). Comunicación institucional y politica. Madrid: Fragua.

Romani, Vicente (2004). Ecologia de la comunicación. Hondariibia, Guipúzkoa: HIRU.

Salvador, Neus Arqués (2006). Aprender comunicación digital. Barcelona: Paidos Iberica.

Serrano, Sebastia (2004). Comprender la comunicación. Barcelona: Paidos Iberica.

Yanes Mesa, Rafael (2009). Comunicación politica y periodismo. Madrid: Fragua.

Zuñiga, Joseba (1998). Comunicación audiovisual. Andoain, Guipúzkoa: Escuela de Cine y Video de Andoain.

\section{References}

[1] A. Abbott ( 2001). Chaos of Disciplines, Chicago: University of Chicago Press.

[2] Andrzej Borowski, International Letters of Social and Humanistic Sciences 14 (2014) $33-41$.

[3] J. A. Anderson (1996). Communication Theory: Epistemological Foundation, New York, Guilford Press.

[4] C. R. Berger, S. H. Chafee (1987). The study of communication as a science. In C. R. Berger \& S. H. Chafee (Eds.), Handbook of Communication Science, Newbury Park, CA: Sage, pp. 15-19. 
[5] Andrzej Borowski, International Letters of Social and Humanistic Sciences 14 (2014) 717.

[6] Paula Bajdor, Iwona Grabara, Journal of Studies in Social Sciences 7(2) (2014).

[7] Ştefan Vlăduţescu, American International Journal of Contemporary Research 3(10) (2013).

[8] C. R. Berger, W. B. Gudykunst (1991). Uncertainty and communication. In B. Dervin \& M. Voight (Eds.), Progress in Communication Sciences, Vol. 10, Norwood, NJ: Ablex, pp. 21-66.

[9] C. R. Berger, M. E. Roloff, D. Roskos-Ewoldsen (2010). What is Communication Science? in Berger, C.R., Roloff, M. E, \& Roskos-Ewoldsen, D., (Eds.), The Handbook of Communication Science, ( $2^{\text {nd }}$ ed.), Thousand Oaks, CA, Sage, pp. 3-20.

[10] Andrzej Borowski, International Letters of Social and Humanistic Sciences 14 (2014) 717.

[11]Florentin Smarandache, Ștefan Vlăduțescu, Alina Țenescu (2014). Current Communication Difficulties. Craiova/Columbus: Sitech/Zip Publishing.

[12] M. Borenstein, L. V. Hedges, J. P.T. Higgins, H. R. Rothstein (2009). Introduction to Meta-analysis, Wiley.

[13] J. W. Bowers, J. J. Bradac, (1981). Issues in communication theory: a metatheoretical analysis. In M. Burgoon (Ed.), Communication Yearbook 5, pp. 1-29.

[14] Sebastian Kot, Beata Ślusarczyk (2014). IT Role in Supply Chain Collaboration. Current Communication Difficulties, 165.

[15]D. Bulgaru-Iliescu, L. Oprea, D. Cojocaru, A. Sandu, Revista de Cercetare şi Intervenţie Socială (41) (2013) 176-189.

[16]K. Cissna, L. Frey (2009). Routledge Handbook of Applied Communication Research, NY, Routledge. Also available at

[17] http://rasaneh.org/Images/News/AtachFile/2-9-1390/FILE634576392909227500.pdf

[18] P. Cobley, P. J. Schulz (2013). Introduction. In P. Cobley \& P. J. Schulz (Eds.), Theories and Models of Communication, Berlin/Boston, Walter de Gruyter, pp. 1-16.

[19] Ştefan Cojocaru (2005). Metode apreciative în asistenţa socială: ancheta, supervizarea şl managementul de caz. Polirom.

[20]R. T. Craig, Communication Theory 9(2) (1999) 119-161.

[21]R. T. Craig, Revue internationale de communication sociale et publique 2 (2009) 7-12.

[22] O. M. Cuichi, C. Bragaru, S. Cojocaru, Revista de Cercetare şi Intervenţie Socială, (36) (2012) 31-43.

[23]B. Dervin, M. Voight, (Eds.) (1991). Progress in Communication Sciences, Vol. 10, Norwood, NJ: Ablex Publishing Corp.

[24]R. Escarpit (1973). L'Écrit et la communication, Paris, PUF.

[25] S. M. Radu, International Letters of Social and Humanistic Sciences (16) (2014) 184193. 
[26] G. Genosko (2012). Remodeling Communication. From wwii to the www, Toronto, University of Toronto Press.

[27]Tomáš Hes, Alena Neradová, Karel Srnec, International Letters of Social and Humanistic Sciences 7 (2013) 55-75.

[28]E. A. Griffin (1997). A First Look at Communication Theory, (3 ${ }^{\text {rd }}$ ed.), New York, McGraw-Hill.

[29] Janusz Grabara, Paula Bajdor (2014). Organizational culture difficulties in SME enterprises. Topical Communication Uncertainties, 42.

[30] J. H. Gasderell, International Letters of Social and Humanistic Science 22 (2014) 85-91.

[31] Max G. Craig, Journal of Studies in Social Sciences 8(1) (2014).

[32]L. Grossberg (1982). Does communication theory need intersubjectivity? Toward an immanent philosophy of interpersonal communication. In J. K. Burgoon (Ed.), Communication Yearbook 6, Beverly Hills, CA, Sage, pp. 171-205.

[33]H. Hardt (1992). Critical Communication Studies. Communication, History, and Theory in America, London, Routledge.

[34] G. Rajović, J. Bulatović, International Letters of Social and Humanistic Sciences (06) (2013) 24-35.

[35] N. L. Harper (1980). Human Communication Theory: A History of a Paradigm, Boston, Cook.

[36] J. C. Herrero (2009). Manual de teoría de la información y de la comunicación, Universitas, Madrid.

[37] M. R. Islam, S. Cojocaru, ABA Siti Hajar, HA Wahab, S. Sulaiman, Revista de Cercetare si Interventie Sociala 46 (2014) 255-272.

[38] Y. Jeanneret, B. Olivier (Eds.) (2004). Les sciences de l'information et de la communication. Paris, CNRS Editions.

[39] Andrezj Borowski, International Letters of Social and Humanistic Sciences 6 (2013) 8690.

[40] Janusz Grabara, Michal Kolcun, Sebastian Kot, International Journal of Education and Research 2(2) (2014).

[41]D. L. Kincaid (Ed.) (1987). Communication Theory: Eastern and Western Perspectives, San Diego, Academic Press.

[42] Antonio Sandu, Elena Unguru (2014). Acțiune comunicativă, justiție deliberativă și restaurativă. București: Editura Tritonic.

[43] M. W. Lipsey, D. Wilson (2000). Practical Meta-Analysis. Applied Social Research Methods, SAGE Publications.

[44] M. Martin Serrano (2007). Teoría de la comunicación, McGrow-Hill Interamericana de España, Madrid.

[45] A. Caras, A. Sandu, Procedia-Social and Behavioral Sciences 149 (2014) 142-151.

[46] A. Sandu, Postmodern Openings (3) (2014) 49-66.

[47]L. Patacchini (2013). Teoria della comunicazione, Hoepli. 
[48]C. Pavit (2001). Philosophy of Science and Communication Research, New York, Nova Science.

[49] M. G. Mangra, E. A. Cotoc, A. Traistaru, Journal of Studies in Social Sciences 6(1) (2013).

[50]Pavit, C. (2000). Answering questions requesting scientific explanations for communication. Communication Theory, 10(4), 379-404.

[51] J. L. Piñuel Raigada (1997). Teoría de la comunicación y gestion de las organizaciónes, Sintesis, Madrid.

[52]Florentin Smarandache, Stefan Vladutescu, Revista de Cercetare şi Intervenţie Socială, (46) (2014) 243-254.

[53]A. C. Strunga, C. M. Bunaiasu, Revista de cercetare şi intervenţie socială (40) (2013) 61-77.

[54] Ştefan Vlăduţescu, European Scientific Journal 9(32) (2013).

[55] Ștefan Vlăduțescu, Journal of Studies in Social Sciences 7(1) (2014).

[56] Dan Valeriu Voinea, Revista de Stiinte Politice (2011).

[57] Andrzej Borowski, International Letters of Social and Humanistic Sciences 27 (2014) 100-110.

[58] Jason L. Powell, International Letters of Social and Humanistic Sciences 17(1) (2014) $1-60$.

\section{Electronic references}

http://conocimiento.incae.edu/ES/biblioteca/sistema-

bibliotecas/nicaragua/ncminibi/ncdic2000mini.php

http://libros.about.com/od/Apoyo/tp/Libros-En-Internet-Como-Y-Donde-Adquirirlos.htm

http:// www.casadellibro.com

http:// www. ocio.elcorteingles.es/libros

http:// www.iberlibro.com

http:// www.ibs.it

http:// www.inmondadori.it

http:// www.hoepli.it

http://www.celesa.es/home.htm

http://www.porrua.com.mx/index2.html

http://libreria.interbook.net/BusquedaTematica.asp

http://www.j-libros.com/

http://www.lsf.com.ar/

http://www.gandhi.com.mx/cgi-bin/gandhi.storefront

http://www.elsotano.com.mx/, http://www.tematika.com.ar/

Pages last consulted on the 1st of July, 2014. 


\section{ANNEXES}

\section{Italian bookshops}

\begin{tabular}{|c|c|c|c|}
\hline & \multicolumn{3}{|c|}{ Filters/Categories/Domains in online bookshops } \\
\hline Titles & $\begin{array}{l}\text { Online bookshop } \\
\text { http://www.ibs.it }\end{array}$ & $\begin{array}{c}\text { http://www.inmondadori. } \\
\text { it }\end{array}$ & http://www.hoepli.it \\
\hline $\begin{array}{l}\text { 1. Fondamenti } \\
\text { di psicologia } \\
\text { della } \\
\text { comunicazione }\end{array}$ & $\begin{array}{l}\text { •Psicologia " } \\
\frac{\text { Psicologia }}{\text { gruppo o }} \frac{\text { Sociale, di }}{\text { collettiva }}\end{array}$ & \begin{tabular}{|l}
$\frac{\text { Università e professioni }}{\text { Politica e Società }}{ }^{\prime} "$ \\
$\frac{\text { Studi interdisciplinari e }}{\text { culturali }}$
\end{tabular} & $\begin{array}{l}\frac{\text { SCIENZE UMANE }}{\text { E SOCIALI } \gg} \\
\frac{\text { PSICOLOGIA } \gg}{\underline{\text { TESTI E STUDI }}}\end{array}$ \\
\hline $\begin{array}{c}\text { 2. La } \\
\text { comunicazione } \\
\text { interculturale }\end{array}$ & $\begin{array}{l}\frac{\text { Società, politica e }}{\text { comunicazione }} \\
\text { Studi }\end{array}$ & $\begin{array}{c}\begin{array}{c}\text { Libri italiani } \\
\text { Politica e Società }\end{array} \\
\frac{\text { Studi interdisciplinari e }}{\underline{\text { culturali }}}\end{array}$ & $\begin{array}{l}\frac{\text { SCIENZE UMANE }}{\text { E SOCIALI } \gg} \\
\text { PSICOLOGIA } \gg \\
\text { COMUNICAZIONE }\end{array}$ \\
\hline $\begin{array}{c}\text { 3. La } \\
\text { comunicazione } \\
\text { non verbale }\end{array}$ & - Psicologia & $\mid \frac{\text { Università e professioni }}{\text { Psicologia e Filosofia }}{ }_{\text {Psicologia }} "$ & $\begin{array}{l}\frac{\text { SCIENZE UMANE }}{\text { E SOCIALI } \gg} \\
\text { PSICOLOGIA } \gg \\
\text { COMUNICAZIONE }\end{array}$ \\
\hline $\begin{array}{l}\text { 4. Etica della } \\
\text { comunicazione }\end{array}$ & - $\frac{\text { Filosofia }}{\text { filosofia morale }}$ & $\mid \begin{array}{l}\text { Università e professioni }{ }^{2} \\
\text { Psicologia e Filosofia }{ }^{\prime} \\
\text { Filosofia: Specifiche aree }\end{array}$ & 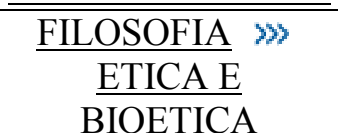 \\
\hline $\begin{array}{l}\text { 5. Manuale di } \\
\text { comunicazione } \\
\text { assertiva }\end{array}$ & $\begin{array}{c}\begin{array}{c}\text { Salute, famiglia e } \\
\text { benessere personale }\end{array} \\
\frac{\text { Self-help e }}{\text { valorizzazione }} \\
\begin{array}{c}\text { personale "Self-help: } \\
\frac{\text { opere divulgative }}{\text { Assertività, }}\end{array} \\
\frac{\text { motivazione e }}{\text { autostima }}\end{array}$ & $\mid \frac{\mid \begin{array}{l}\text { Università e professioni } \\
\text { Psicologia e Filosofia }\end{array}}{\underline{\text { Psicologia }}} "$ & $\begin{array}{c}\frac{\text { ECONOMIA, }}{\text { MARKETING, }} \\
\frac{\text { FINANZA E }}{\text { MANAGEMENT }} \\
\frac{\text { MA }}{\text { MANAGEMENT }} \\
\frac{\text { COMUNICAZIONE }}{\text { AZIENDALE }}\end{array}$ \\
\hline $\begin{array}{l}\text { 6. Fare } \\
\text { comunicazione. } \\
\text { Teoria ed } \\
\text { esercizi }\end{array}$ & $\begin{array}{l}\text { - } \frac{\text { Società, politica e }}{\text { comunicazione }} \\
\frac{\text { Studi }}{\text { interdisciplinari }}\end{array}$ & $\mid \begin{array}{l}\frac{\text { Università e professioni }}{\text { Politica e Società }} \text { » Studi } \\
\underline{\text { interdisciplinari e }} \\
\underline{\text { culturali }}\end{array}$ & 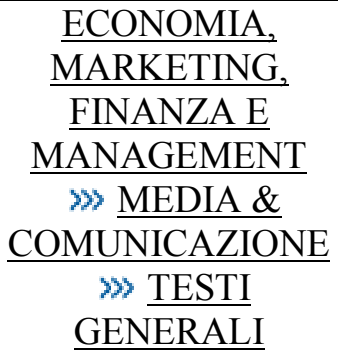 \\
\hline $\begin{array}{c}7 . \\
\text { Comunicazione, } \\
\text { cultura, società }\end{array}$ & $\begin{array}{l}\begin{array}{c}\text { Società, politica e } \\
\text { comunicazione }\end{array} \\
\frac{\text { Argomenti d'interesse }}{\text { generale }} \text { "Studi sui } \\
\frac{\text { mezzi di }}{\text { comunicazione di }} \\
\text { massa }\end{array}$ & $\begin{array}{l}\text { Università e professioni } » \\
\text { Politica e Società " } \\
\text { Comunicazione e Media }\end{array}$ & $\begin{array}{l}\frac{\text { SCIENZE UMANE }}{\text { E SOCIALI } \gg} \\
\text { PSICOLOGIA } \gg \\
\text { COMUNICAZIONE }\end{array}$ \\
\hline & & & \\
\hline
\end{tabular}




\begin{tabular}{|c|c|c|c|}
\hline $\begin{array}{l}\text { 8. Il linguaggio } \\
\text { segreto del } \\
\text { corpo. La } \\
\text { comunicazione } \\
\text { non verbale }\end{array}$ & $\begin{array}{c}\begin{array}{c}\text { - Salute, famiglia e } \\
\text { benessere personale }\end{array} \\
\frac{\text { Self-help e }}{\text { valorizzazione }}\end{array}$ & Libri italiani & $\begin{array}{l}\frac{\text { SCIENZE UMANE }}{\text { E SOCIALI } \gg} \\
\text { PSICOLOGIA } \gg \\
\text { COMUNICAZIONE }\end{array}$ \\
\hline $\begin{array}{l}\text { 9. La } \\
\text { comunicazione } \\
\text { politica }\end{array}$ & $\begin{array}{l}\text { - } \frac{\text { Società, politica e }}{\text { comunicazione }} " \\
\frac{\text { Politica e governo }}{\text { Scienza e teoria }} \\
\text { politica }\end{array}$ & \begin{tabular}{|l}
$\frac{\text { Università e professioni }}{\text { Politica e Società }}{ }^{\text {Ideologie e Teorie }}$ \\
$\frac{\text { politiche }}{}$
\end{tabular} & $\begin{array}{l}\frac{\text { SCIENZE UMANE }}{\text { E SOCIALI } \gg} \\
\text { SCIENZE } \\
\text { POLITICHE } \gg \\
\text { TEORIA POLITICA }\end{array}$ \\
\hline $\begin{array}{l}\text { 10. Le scienze } \\
\text { della } \\
\text { comunicazione. } \\
\text { Modellie } \\
\text { percorsi } \\
\text { disciplinari }\end{array}$ & $\begin{array}{l}-\frac{\text { Società, politica e }}{\text { comunicazione }} \\
\frac{\text { Studi }}{\text { interdisciplinari }} \\
\frac{\text { Studi sulla }}{\text { comunicazione }}\end{array}$ & $\begin{array}{c}\frac{\text { Libri italiani }}{\text { Società }} " \text { Politica e } \\
\text { interdisciplinari e } \\
\text { culturali }\end{array}$ & $\begin{array}{l}\frac{\text { SCIENZE UMANE }}{\text { E SOCIALI } \gg} \\
\text { PSICOLOGIA } \gg \\
\text { COMUNICAZIONE }\end{array}$ \\
\hline $\begin{array}{l}\text { 11. Correggimi } \\
\text { se sbaglio. } \\
\text { Strategie di } \\
\text { comunicazione } \\
\text { per appianare } i \\
\text { conflitti nelle } \\
\text { relazioni di } \\
\text { coppia }\end{array}$ & $\frac{\begin{array}{c}\text { Salute, famiglia e } \\
\text { benessere personale }\end{array}}{\frac{\text { Famiglia e salute }}{\text { Relazioni familiari }} "}$ " & 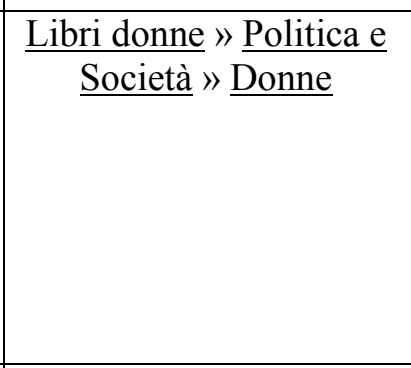 & $\begin{array}{l}\frac{\text { SCIENZE UMANE }}{\text { E SOCIALI } \gg} \\
\frac{\text { PSICOLOGIA }}{\text { COPPIA }}\end{array}$ \\
\hline $\begin{array}{l}\text { 12. Sociologia } \\
\text { della } \\
\text { comunicazione }\end{array}$ & $\begin{array}{l}\cdot \frac{\text { Società, politica e }}{\text { comunicazione }} \\
\frac{\text { Sociologia e e }}{\text { antropologia }} \\
\underline{\text { Sociologia }}\end{array}$ & 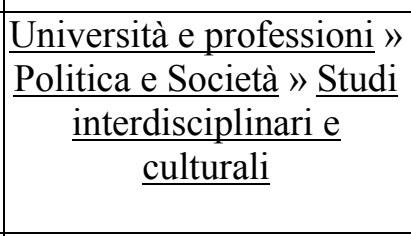 & 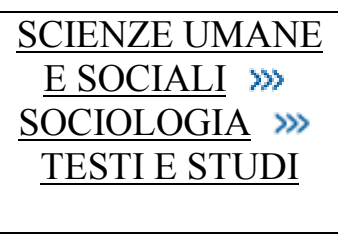 \\
\hline $\begin{array}{c}\text { 13. Teoria e } \\
\text { tecniche della } \\
\text { comunicazione } \\
\text { pubblica }\end{array}$ & 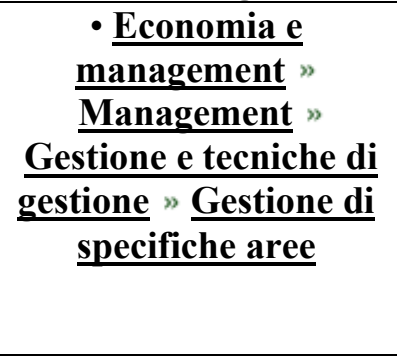 & $\begin{array}{c}\text { Università e professioni } » \\
\underline{\text { Economia, Diritto e }} \\
\text { Lavoro » }{ }^{\text {Management }}\end{array}$ & $\begin{array}{c}\frac{\text { ECONOMIA, }}{\frac{\text { MARKETING, }}{\text { FINANZA E }}} \\
\frac{\text { MANAGEMENT }}{\gg \text { MEDIA \& }} \\
\frac{\text { COMUNICAZIONE }}{\text { } \gg \text { TESTI }} \\
\text { GENERALI }\end{array}$ \\
\hline $\begin{array}{l}\text { 14. Social } \\
\text { network. } \\
\text { Comunicazione } \\
\text { e marketing }\end{array}$ & $\begin{array}{c}\begin{array}{c}\text { Società, politica e } \\
\text { comunicazione }\end{array} \\
\frac{\text { Argomenti d'interesse }}{\text { generale " Studi sui }} \\
\frac{\text { mezzi di }}{\text { comunicazione di }} \\
\text { massa }\end{array}$ & $\frac{\text { Università e professioni }}{\frac{\text { Informatica e Web }}{\text { Social media }}} "$ & 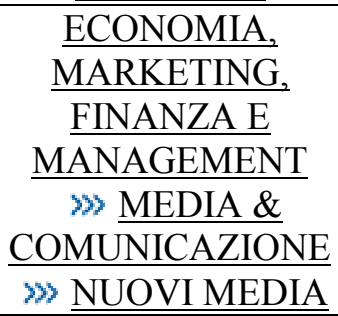 \\
\hline
\end{tabular}




\begin{tabular}{|c|c|c|c|}
\hline $\begin{array}{l}\text { 15. Le origini } \\
\text { della } \\
\text { comunicazione } \\
\text { umana }\end{array}$ & $\begin{array}{l}\text { - } \frac{\text { Società, politica e }}{\text { comunicazione }} \\
\frac{\text { Studi }}{\text { interdisciplinari }} \\
\frac{\text { Studi sulla }}{\text { comunicazione }}\end{array}$ & Libri italiani & $\begin{array}{l}\text { SCIENZE UMANE } \\
\text { E SOCIALI » } \\
\text { ANTROPOLOGIA } \\
\text { » EVOLUZIONE }\end{array}$ \\
\hline $\begin{array}{l}\text { 16. Hapù. } \\
\text { Manuale di } \\
\text { tecnica della } \\
\text { comunicazione } \\
\text { pubblicitaria }\end{array}$ & 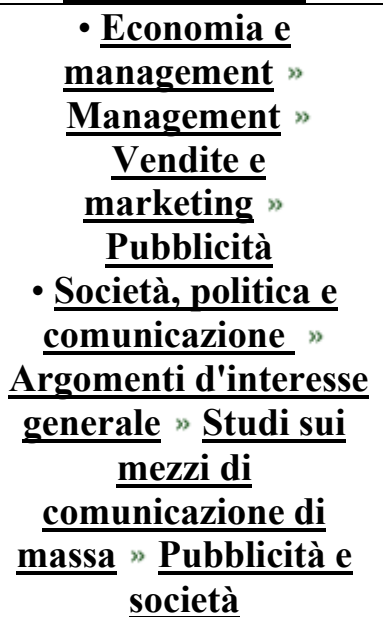 & 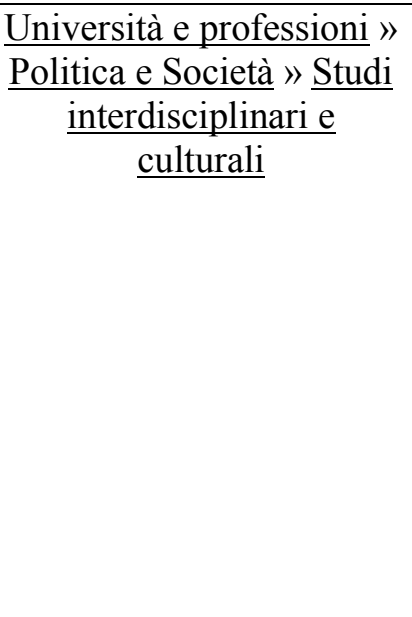 & $\begin{array}{l}\frac{\text { ECONOMIA, }}{\text { MARKETING, }} \\
\text { FINANZA E } \\
\text { MANAGEMENT } \\
\gg \frac{\text { MARKETING \& }}{\text { VENDITA } \gg ~} \\
\underline{\underline{\text { PUBBLICITÀ }}}\end{array}$ \\
\hline
\end{tabular}

\section{Spanish bookshops}

\begin{tabular}{|c|c|c|c|}
\hline & \multicolumn{3}{|c|}{ Filters/Categories/Domains in online bookshops } \\
\hline Titles & $\begin{array}{c}\text { Online bookshop } \\
\text { www.casadellibro.com }\end{array}$ & $\begin{array}{c}\text { ocio.elcorteingles.es/libro } \\
\mathrm{S}\end{array}$ & www.iberlibro.com \\
\hline $\begin{array}{l}\text { 1. Derecho de la } \\
\text { comunicación }\end{array}$ & $\begin{array}{l}\text { - } \underline{\text { Derecho }} \\
\text { - } \underline{\text { Derecho }} \\
\text { administrativo }\end{array}$ & $\begin{array}{c}\underline{\text { Derecho }-} \\
\underline{\text { Derecho }, \underline{\text { Derecho }}} \\
\underline{\text { Constitucional }}\end{array}$ & No relevant domain \\
\hline $\begin{array}{l}\text { 2. La gran guia } \\
\text { del lenguaje no } \\
\text { verbal }\end{array}$ & $\begin{array}{c}\text { - Psicología y } \\
\text { - Comunicación no } \\
\text { verbagogía }\end{array}$ & Autoayuda - Autoayuda & No relevant domain \\
\hline $\begin{array}{l}\text { 3. Comunicación } \\
\text { eficaz }\end{array}$ & $\begin{array}{l}\text {-Psicología y } \\
\text { Pedagogía } \\
\text { - Hablar en público }\end{array}$ & Autoayuda - Autoayuda & No relevant domain \\
\hline $\begin{array}{l}\text { 4. Enciclopedia } \\
\text { de la } \\
\text { comunicación }\end{array}$ & $\begin{array}{l}\text { - } \frac{\text { Ciencias Políticas y }}{\text { Sociales }} \\
\text { - } \underline{\text { Comunicación }} \\
\text { - } \frac{\text { Ciencias de la }}{\underline{\text { información }}}\end{array}$ & $=$ & No relevant domain \\
\hline $\begin{array}{l}\text { 5. Teoria de la } \\
\text { comunicación } \\
\text { social }\end{array}$ & $\begin{array}{l}\text { - } \frac{\text { Psicología y }}{\text { Pedagogía }} \\
\text { - Pedagogía } \\
\text { - Pedagogía social }\end{array}$ & $\frac{\text { Novela - Narrativa - }}{\text { Narrativa }}$ & No relevant domain \\
\hline $\begin{array}{c}6 . \\
\text { Comunicación, } \\
\text { ciencia e } \\
\text { historia }\end{array}$ & $\begin{array}{l}\text { - } \frac{\text { Ciencias Políticas y }}{\underline{\text { Sociales }}} \\
\frac{\text {-Comunicación }}{\text {-Ciencias de la }} \\
\underline{\text { información }}\end{array}$ & $\frac{\text { Novela - Narrativa - }}{\text { Narrativa }}$ & relevant domain \\
\hline
\end{tabular}




\begin{tabular}{|c|c|c|c|}
\hline $\begin{array}{l}\text { 7. Comunicación } \\
\text { y lenguaje }\end{array}$ & $\begin{array}{c}\text { - Filología } \\
\text { - Estudios lingüísticos } \\
\text { - Estudios y ensayos }\end{array}$ & $\frac{\text { Novela - Narrativa - }}{\text { Narrativa }}$ & No relevant domain \\
\hline $\begin{array}{l}\text { 8. Comunicación } \\
\text { de crisis }\end{array}$ & $\begin{array}{l}\text { - Economía } \\
\text { - } \text { Marketing y } \\
\text { publicidad }\end{array}$ & $\begin{array}{c}\frac{\text { Empresa - Empresa }}{\text { Organización }} \\
\underline{\text { Empresarial }}\end{array}$ & No relevant domain \\
\hline $\begin{array}{l}\text { 9. Comunicación } \\
\text { e integracion } \\
\text { personal }\end{array}$ & 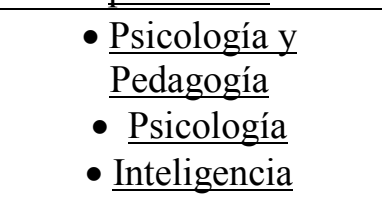 & $=$ & No relevant domain \\
\hline $\begin{array}{c}\text { 10. La otra } \\
\text { comunicación. } \\
\text { Comunicación } \\
\text { no verbal }\end{array}$ & $\begin{array}{c}\text { - Empresa } \\
\text { - Administración y } \\
\text { dirección empresarial }\end{array}$ & $\begin{array}{l}\frac{\text { Ciencias Humanas - }}{\text { Periodismo }}, \underline{\text { Manuales y }} \\
\underline{\text { Estudios }}\end{array}$ & No relevant domain \\
\hline $\begin{array}{l}11 . \\
\text { Comunicación } \\
\text { institucional y } \\
\text { politica }\end{array}$ & $\begin{array}{l}\text { - } \frac{\text { Ciencias Políticas y }}{\text { Sociales }} \\
\text { - } \frac{\text { Comunicación }}{\text { Ciencias de la }} \\
\underline{\underline{\text { información }}}\end{array}$ & $\frac{\text { Novela - Narrativa - }}{\underline{\text { Narrativa }}}$ & No relevant domain \\
\hline $\begin{array}{l}\text { 12. Ecologia de } \\
\text { la comunicación }\end{array}$ & $\begin{array}{l}\text { - } \frac{\text { Ciencias Políticas y }}{\text { Sociales }} \\
\text { - } \frac{\text { Comunicación }}{\text { - } \frac{\text { Ciencias de la }}{\text { información }}}\end{array}$ & $\begin{array}{c}\text { Historia }- \\
\text { Historia Universal }\end{array}$ & No relevant domain \\
\hline $\begin{array}{c}\text { 13. Aprender } \\
\text { comunicación } \\
\text { digital }\end{array}$ & $\begin{array}{l}\text { - } \frac{\text { Ciencias Políticas y }}{\text { Sociales }} \\
\text { - } \underline{\text { Comunicación }} \\
\text { - } \frac{\text { Ciencias de la }}{\text { información }}\end{array}$ & $\begin{array}{l}\text { Empresa }- \\
\text { Empresa, Marketing, } \\
\text { Fundamentos y Tipos }\end{array}$ & No relevant domain \\
\hline $\begin{array}{l}\text { 14. Comprender } \\
\text { la comunicación }\end{array}$ & $\begin{array}{l}\text { - } \frac{\text { Ciencias Políticas y }}{\text { Sociales }} \\
\text { - } \frac{\text { Comunicación }}{\text { Ciencias de la }} \\
\text { información }\end{array}$ & $\frac{\text { Novela - Narrativa - }}{\text { Narrativa }}$ & No relevant domain \\
\hline $\begin{array}{c}15 . \\
\text { Comunicación } \\
\text { politica y } \\
\text { periodismo }\end{array}$ & $\begin{array}{l}\text { - } \frac{\text { Ciencias Políticas y }}{\text { Sociales }} \\
\text { - } \underline{\text { Comunicación }} \\
\text { - } \underline{\text { Periodismo }}\end{array}$ & $\begin{array}{l}\frac{\text { Ciencias Humanas - }}{\text { Periodismo }}, \underline{\text { Manuales y }} \\
\underline{\text { Estudios }}\end{array}$ & No relevant domain \\
\hline $\begin{array}{c}16 . \\
\text { Comunicación } \\
\text { audiovisual }\end{array}$ & $\begin{array}{l}\text { - } \frac{\text { Ciencias Políticas y }}{\text { Sociales }} \\
\text { - } \frac{\underline{\text { Comunicación }}}{-\frac{\text { Ciencias de la }}{\text { información }}}\end{array}$ & $\frac{\text { Psicología y pedagogía - }}{\underline{\text { Pedagogía }}}$ & No relevant domain \\
\hline
\end{tabular}

